Diabetologia 8, 12-18 (1972)

(C) by Springer-Verlag 1972

\title{
Epidemiological Researches on Diabetes Mellitus in Roumanian Urban and Rural Population
}

\author{
I. Mince, C. Dumitresco, S. Campeano, N. Mmealache, M. Pîrvolesod, D. Covanov, St. Georgescu, \\ V. Nuteand, V. Vastiesco, V. Mironescu, L. Aron, E. Antonesco, D. Ionesce, M. Bolea-Feldman \\ The Centre of Metabolic Diseases and Nutrition Hospital "Dr. I. Cantacuzino", Bucharest, Roumania
}

Received: May 25, 1971, accepted: November 26, 1971

\begin{abstract}
Summary. This paper presents the methodology and the results of screening for Diabetes mellitus in large population groups. The investigation consisted of two phases: the detection of glycosuria and blood sugar level $2 \mathrm{~h}$ after on oral glucose load; and afterwards, the performance of GTT on people with blood sugar levels above the limits defined as normal for each age group. - The screening of 1314 subjects from a rural population and 7113 from an urban population, between 25 and 65 years of age indicated a prevalence of Diabetes mellitus of $1.44 \%$ and $3.7 \%$ respectively. This estimate includes diabetics already known to a special medical centre. - $74.5 \%$ of the urban population and $88.7 \%$, of the rural population were included in the screening. - Obesity was found in $51 \%$ and $69 \%$ of the newly found urban and rural diabetics, respectively. In $2.15 \%$ of the group, glycosuria was found with normal blood sugar levels during GTT, suggesting that this group should be specially recorded and subjected to periodical survey. - Screening for Diabetes mellitus solely by glycosuria testing is both inadequate and erroneous.
\end{abstract}

Recherches épidémiologiques concernant le diabète sucré dans la population urbaine et rurale de la Roumanie

Résumé. Les auteurs exposent la méthodologie et les résultats obtenus dans le dépistage du diabète sucré parmi de larges groupes de population. - L'exploration a été effectuée en deux phases: la glycosurie et la glycémie prise deux heures après la charge en glucose et après l'exploration par le test du GTT chez des sujets ayant des taux de glycémie dépassant les limites définies comme normales pour chaque groupe d'âge. - Chez un groupe de 1314 personnes parmi la population rurale et 7113 parmi la population urbaine, âgées de 25 à 65 ans, l'incidence du diabète sucré a été respectivement de $1.44 \%$ et de $3.7 \%$. Dans le calcul final on a considéré aussi les diabétiques déjà en traitement dans un centre médical spécial. Des investigations plus approfondies ont été faites sur $74.5 \%$ des malades du milieu urbain dépistés et sur $88.7 \%$ des malades provenant du milieu rural. - L'incidence de l'obésité parmi les diabétiques dépistés a été de $51 \%$ dans la population. urbaine et de $69 \%$ dans la population rurale. - A part les cas de diabète sucré, les recherches en masse ont montré une proportion de $2.15 \%$ de glycosurie pour une glycémie normale lors du GTT, ce qui suggère que cette catégorie de malades devrait être recensée dans un centre médical et soumise à un controle périodique. - En même temps on a démontré que la méthode de dépistage du diabète sucré seulement d'après la glycosurie est insuffisante et erronée.

Epidemiologische Studien über den Diabetes mellitus in der rumänischen Stadt- und Landbevölkerung

Zusammenfassung. Es werden die Methoden und Resultate bei der Aufdeckung von Diabetikern in großen Bevölkerungsgruppen dargelegt. Die Untersuchungen erfolgten in zwei Teilen. Zunächst wurden der Harn- und. Blutzucker zwei Stunden nach einer Glucosebelastung ermittelt. Später wurden bei den Personen mit im Vergleich zu den Normalwerten ihrer Altersgruppe erhöhten Blutzuckerwerten detailliertere Glucosetoleranzteste durchgeführt. - In einer Gruppe von 1314 Personen einer Landbevölkerung und in einer Gruppe von 7113 Personen einer Stadtbevölkerung zwischen 25 und 65 Jahren war die Häufigkeit des Diabetes $1.44 \%$ bzw. 3.7\% . In der Endrechnung wurden schon bekannte Diabetiker, die in Diabeteszentren behandelt wurden, mit eingerechnet. An $74.5 \%$ der Stadtbevölkerung und $88.7 \%$ der Landbevölkerung wurden weitere Untersuchungen angeschlossen. Die Häufigkeit der Übergewichtigkeit unter den neu entdeckten Diabetikern lag bei $51 \%$ in der Stadtund bei $69 \%$ in der Landbevölkerung. Neben den Diabetikern ergaben die Massenuntersuchungen in $2.15 \%$ der Fälle eine Glykosurie bei normalen Blutzuckerwerten während des Glucosetoleranztestes. Diese Gruppe von Patienten benötigte eine ständige Überwachung. Gleichzeitig wurde festgestellt, daß die Aufdeckung von Diabetikern allein mit dem Harnzuckernachweis unzureichend und fehlerhaft ist.

Key words: Diabetes mellitus, epidemiology of diabetes, obesity, renal glycosuria, prevalence of diabetes, prevalence of obesity.
There is a conspicuous and alarming growth of morbidity, due to degenerative chronic diseases, among which diabetes mellitus is of great importance. Early diagnosis is one of the most important prophylactic factors of these conditions. For this purpose, a systematic detection campaign carried out on large groups of the population can be an efficient method; it should also permit accurate evaluation of morbidity rates for the whole population, with implications affecting the organisation of mass prophylaxis.

In the determination of the morbidity rate of diabetes mellitus two principal methods of detection have been applied [1]:

a) The investigation of postprandial glycosuria, generally followed by subsequent glucose tolerance test (GTT) in the suspect persons, and

b) Investigation of postprandial blood sugar level, generally followed by a test for glycosuria.

The International Diabetes Federation recommends that population investigations for diabetes should be carried out in the following manner: $[7,16]$.

1. The determination of blood sugar and urine 
levels $2 \mathrm{~h}$ after a meal which must contain at least $50 \mathrm{~g}$ carbohydrate.

2. The performance of a complete glucose tolerance test in the persons whose initial tests suggest the possibility of diabetes. This investigation should be carried out in all the subjects having glycosuria as well as a blood sugar level of $130 \mathrm{mg} / 100 \mathrm{ml}$ or more (Hagedorn-Jensen).

Most of the researches carried out with the first method (a) (1930-1950) showed a relatively low morbidity rate $[3,4,5,6$, .

Such an epidemiological study was also made in Roumania in 1962. This showed that in Bucharest, the prevalence rate, at that time, was estimated at about $1.1 \%[15,16]$. The method of active detection, based on the postprandial blood sugar measurement represented an important advance. Its application began about 1950, different variants being used. By this approach a 5 to 8 times higher prevalence rate was found than by the first method $[7,8,9,10,11,12,13$, 14].

Taking into account the discrepancy between the prevalence rate estimated for Bucharest and the rising
In assessing the results of the glucose tolerance test, patterns were regarded as pathological when one of the following three values was abnormal: (1) fasting blood sugar over $120 \mathrm{mg} / 100 \mathrm{ml}$, (2) blood sugar values in a GTT exceeding $160 \mathrm{mg} / 100 \mathrm{ml}$ after one hour, or (3) exceeding $130 \mathrm{mg} / 100 \mathrm{ml} 2$ hours after the ingestion of glucose.

\section{Results}

In the initial screening 75 persons, representing $5.7 \%$ of the total number of the investigated subjects, were found to have blood glucose values over $130 \mathrm{mg} /$ $100 \mathrm{ml}$, two hours after glucose load. All these 75 subjects were subsequently submitted to G.T.T. in the laboratories of the Clinic of Metabolic Diseases and Nutrition. Abnormal patterns as defined above were obtained in $1.44 \%$, of the original population, thus exceeding the proportion found for urban areas (Bucharest) in 1962, (Table 1). This investigation was the first to be carried out in Roumania, with the method of ingestion by the fasting subject of $100 \mathrm{~g}$ glucose. The results obtained illustrate the value of the method in mass detection of Diabetes mellitus.

Table 1. Distribution on sex and age groups of the GTT results, of the subjects with blood sugar values over 130 mg\% on the first determination. Diabetes incidence: $1.44 \%$

\begin{tabular}{|c|c|c|c|c|c|c|c|c|c|c|c|c|c|c|c|c|}
\hline \multirow{3}{*}{$\begin{array}{l}\text { Age group } \\
\text { Value } \\
\text { Sexes }\end{array}$} & \multicolumn{4}{|c|}{$17-20$ yrs. } & \multicolumn{4}{|c|}{$21-40$ yrs. } & \multicolumn{4}{|c|}{$41-60$ yrs. } & \multicolumn{4}{|c|}{ over 61 yrs. } \\
\hline & \multicolumn{2}{|c|}{ abnormal } & \multicolumn{2}{|c|}{ normal } & \multicolumn{2}{|c|}{ abnormal } & \multicolumn{2}{|c|}{ normal } & \multicolumn{2}{|c|}{ abnormal } & \multicolumn{2}{|c|}{ normal } & \multicolumn{2}{|c|}{ abnormal } & \multicolumn{2}{|c|}{$\overline{\text { normal }}$} \\
\hline & men & $\begin{array}{l}\text { wom- } \\
\text { en }\end{array}$ & men & $\begin{array}{l}\text { wom- } \\
\text { en }\end{array}$ & men & $\begin{array}{l}\text { wom- } \\
\text { en }\end{array}$ & men & $\begin{array}{l}\text { wom- } \\
\text { en }\end{array}$ & men & $\begin{array}{l}\text { wom- } \\
\text { en }\end{array}$ & men & $\begin{array}{l}\text { wom- } \\
\text { en }\end{array}$ & men & $\begin{array}{l}\text { wom- } \\
\text { en }\end{array}$ & men & $\begin{array}{l}\text { wom- } \\
\text { en }\end{array}$ \\
\hline Number & 0 & 0 & 0 & 0 & 2 & 0 & 8 & 7 & 4 & 4 & 7 & 18 & 4 & 5 & 10 & 6 \\
\hline Total & 0 & & 0 & & 2 & & 15 & & 8 & & 25 & & 9 & & 16 & \\
\hline
\end{tabular}

incidence of Diabetes mellitus, in the rest of the world, a new study was obviously desirable.

The present investigation was carried out separately in rural and urban area in Roumania. Sex, age and the presence of overweight were recorded and their correlation with glycosuria and hyperglycaemia after a standard glucose load was studied.

\section{Diabetes mellitus in Roumanian countryside}

This first investigation was carried out in 1968 on 1314 persons aged between 17 and 70 years (728 women and $586 \mathrm{men}$ ) representing $88.7 \%$ of the whole population of the village of Buda (district Ilfov). No changes in the normal nutrition of the subjects were detected during the few days which preceeded the research.

\section{Method}

Two hours after the ingestion of $100 \mathrm{~g}$ glucose, venous blood samples were taken for blood glucose determination (Hagedorn-Jensen's method) and urine was collected for testing by Clinistix (Ames).

\section{Diabetes mellitus in Roumanian urban areas}

A second investigation for diabetes mellitus was carried out in Bucharest in 1970 involving 7113 adults aged between 25 and 65 years. The study was limited to these groups in view of the rarity of clinically silent diabetes mellitus in the young and the probability of interfering factors in the old. In addition to blood sugar measurement, the range of investigation was widened to include a study of plasma lipids, obesity and arterial disease.

\section{Method}

Before the screening operation, the whole population in the involved district was informed about the aims of the investigation. Personal invitations were distributed to every family.

Blood samples were taken from the fasting subjects at $0700 \mathrm{~h}$. The levels of free and esterified chol. esterol, triglycerides, phospholipids and free fatty acids were subsequently estimated and lipoprotein electrophoresis carried out. Each subject then received $100 \mathrm{~g}$ glucose dissolved in $250 \mathrm{~g}$ water and two hours later a second blood sample was taken for blood sugar 
measurement and urine collected for testing (Hagedorn Jensen method for blood sugar and "Clinistix" for glycosuria).

During the $2 \mathrm{~h}$ interval, personal data and medical histories were recorded from each individual and height, weight, blood pressure (erect and prone), examination of the fundus oculi and electrocardiogram were performed.

In the present study, only the results relating to the frequency of Diabetes mellitus in the investigated population by sex and age groups, will be presented.

Since the fasting and the two hour blood sugar levels vary with age [13], the maximum normal $2 \mathrm{~h}$ blood sugar values were established for each age group, by reference to the values obtained for 100 persons (50 men and 50 women) of each age group.

All these subjects had normal weight, and were without a personal or family history of diabetes mellitus, obesity and arterial hypertension, nor had they any abnormality of the retina or electrocardiogram.

The average blood sugar values were calculated for each age group, as well as the standard deviation and the upper limits for the $2 \mathrm{~h}$ blood sugar.

\section{Results}

The limit levels established are recorded in Fig. 1, although in this work, for the subjects aged between $25-45$ years, only the values above $130 \mathrm{mg} / 100 \mathrm{ml}$ were considered abnormal.

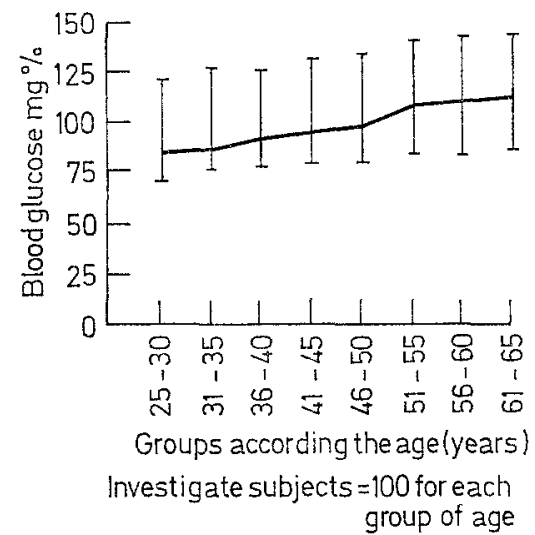

Fig. 1. Normal values for glycaemia, according the age two hours after the glucose meal

The population examined was classified according to these levels and a prevalence of $7.6 \%$ of diabetes mellitus was found among the 7113 tested persons. Among the 3287 men $8.9 \%$ and among the 3826 women $6.3 \%$ were classified as possible diabeties (Fig. 2).

The study was then concentrated on the analysis of the special group of 540 subjects, with newly found elevated blood sugar values.

These subjects were recalled and a full glucose tolerance test [2] carried out.
With the smaller number of patients, the separate consideration of each subject of the group became possible.

For the classification of abnormal tests the same criteria as those mentioned for rural areas were used.

The results obtained (Fig. 2, 3 and 4) show an incidence of Diabetes mellitus which varies with sex and age group, from $0.65 \%$ for men, and $0.46 \%$ for females in the age group of $25-30$ years, up to $8.1 \%$ for men and 8.4 for women in the age group of $61-65$ years.

Within the whole group of 7113 subjects, 332 diabetics were found representing $4.65 \%$ from the studied population. After grouping by sex, Diabetes mellitus was found in 192 men $(5.9 \%)$ and 140 women $(3.65 \%)$ (Table 2, Fig. 4).

Since $74.52 \%$ of the population between 25 and 65 years of the respective area was investigated, an estimate of the number of diabetics in the whole population became possible.

Since the number of diabetics from the investigated district was previously known and registered at the "Antidiabetic centre" from Bucharest (ACB) they

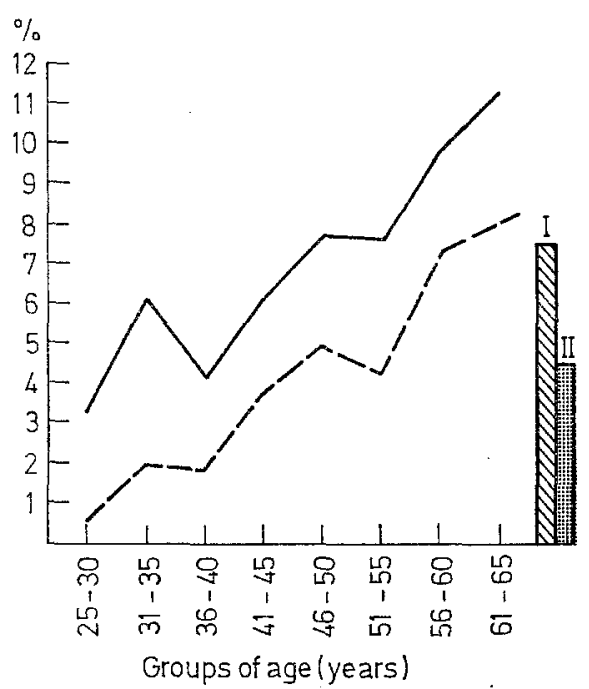

Fig. 2. Results of epidemiological investigations of diabetes mellitus depending on age

I - G.T.T. with one blood glucose determination (Mass investigations)

II - - - G.T.T. after double glucose load (Duncan) (second step of investigation)

were also included in order to obtain the total prevalence of Diabetes (Fig. 3).

Thus for the whole population ranging between 25 and 65 years the prevalence of Diabetes mellitus was estimated to be $4.9 \%$ in the studied area.

For the population from $0-65$ years the prevalence was $3.6 \%$. In the same area there is a prevalence of $3.8 \%$ of known Diabetes mellitus in persons over 65 years. The number of diabetics over 65 years was added to the total number (known and discovered) of 
diabetics under this age, so that the final estimated prevalence of Diabetes mellitus for the whole population of Bucharest became $3.7 \%$ (Fig. 6).

Compared with the previously estimated prevalence (1962) of $1.1 \%$ diabetics $[15,16]$ the newly defined of the disease $[12,17,18,19]$. These findings strongly suggest that special measures are needed for the management of the existing diabetics and the prevention of new cases with their greatly increased risk of eye, kidney and arterial diseases.

Table 2. Distribution on sex and age groups of the subjects and the incidence of diabetes mellitus after Duncan's glucose tolerance test

\begin{tabular}{|c|c|c|c|c|c|c|c|c|c|c|c|c|}
\hline \multirow{3}{*}{$\begin{array}{l}\text { Age group } \\
\text { yrs. }\end{array}$} & \multirow{2}{*}{\multicolumn{2}{|c|}{$\begin{array}{l}\text { Total } \\
\text { Subjects }\end{array}$}} & \multirow{2}{*}{\multicolumn{2}{|c|}{$\begin{array}{l}\text { Total } \\
\text { Diabetics }\end{array}$}} & \multicolumn{4}{|l|}{ Men } & \multicolumn{4}{|c|}{ Women } \\
\hline & & & & & \multicolumn{2}{|c|}{ Subjects } & \multicolumn{2}{|c|}{ Diabetics } & \multicolumn{2}{|c|}{ Subjects } & \multicolumn{2}{|c|}{ Diabeties } \\
\hline & No. & $\%$ & No. & $\%$ & No. & $\%$ & No. & $\%$ & No. & $\%$ & No. & $\%$ \\
\hline $25-30$ & 458 & 100 & 3 & 0.65 & 238 & 51.9 & 2 & 0.84 & 220 & 48.1 & 1 & 0.46 \\
\hline $31-35$ & 598 & 100 & 12 & 2.00 & 293 & 49.0 & 5 & 1.72 & 305 & 51.0 & 7 & 2.30 \\
\hline $36-40$ & 878 & 100 & 17 & 1.94 & 388 & 44.3 & 13 & 3.35 & 490 & 55.7 & 4 & 0.82 \\
\hline $41-45$ & 1045 & 100 & 40 & 3.80 & 459 & 43.9 & 26 & 5.70 & 586 & 56.1 & 14 & 2.40 \\
\hline $46-50$ & 1088 & 100 & 55 & 5.00 & 451 & 42.0 & 36 & 7.90 & 631 & 58.0 & 19 & 3.00 \\
\hline $51-55$ & 836 & 100 & 36 & 4.30 & 368 & 44.0 & 19 & 5.20 & 468 & 56.0 & 17 & 3.65 \\
\hline $56-60$ & 1242 & 100 & 91 & 7.30 & 570 & 45.8 & 51 & 9.00 & 672 & 54.2 & 40 & 5.90 \\
\hline $61-65$ & 968 & 100 & 78 & 8.10 & 514 & 53.0 & 40 & 7.80 & 454 & 47.0 & 38 & 8.40 \\
\hline Total & 7113 & 100 & 332 & 4.65 & 3287 & 46.2 & 192 & 5.90 & 3826 & 53.8 & 140 & 3.65 \\
\hline
\end{tabular}

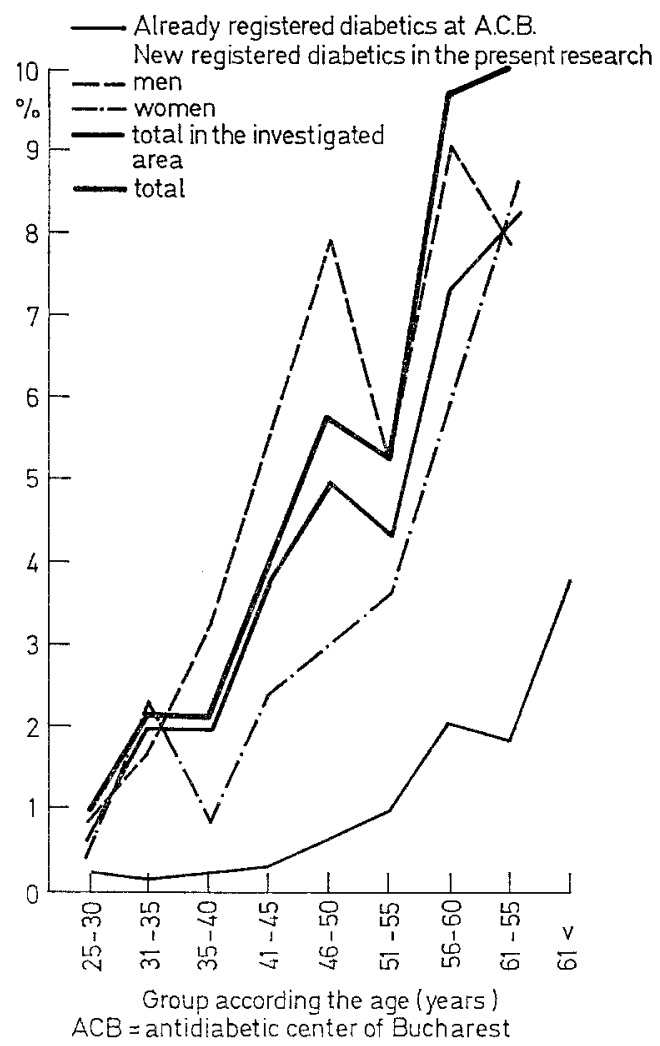

Fig. 3. Incidence of diabetes mellitus

prevalence in the same population group leads to the conclusion that, for each known diabetic person, there are two or even three unknown diabetics in the population.

This high prevalence of Diabetes mellitus, places Roumania, at least when the urban population is considered, among the countries with a high frequency

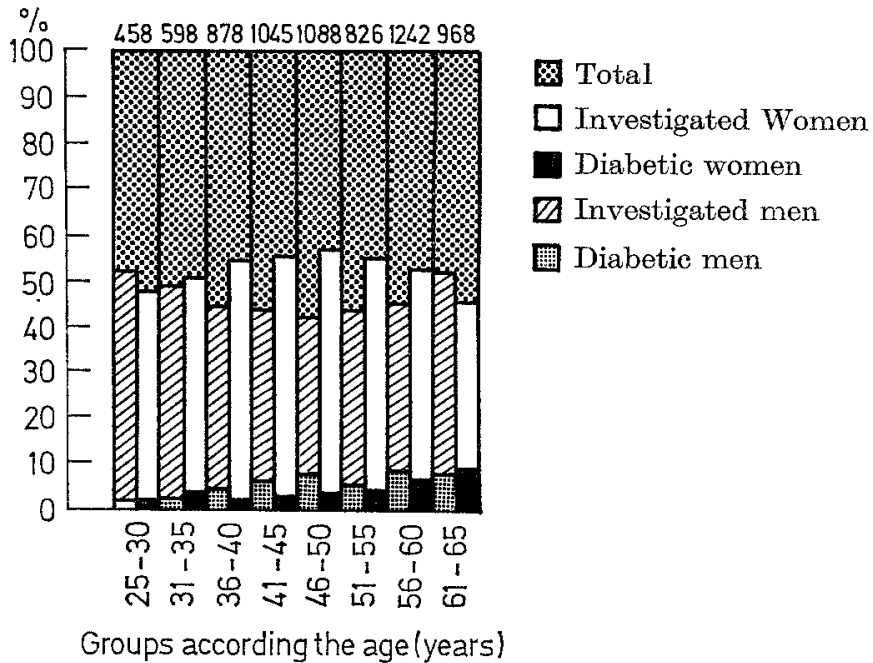

Fig. 4. Distribution-depending on age group, and sex of the diabetes incidence

\section{Correlation between Diabetes and Obesity in the Roumanian population}

Because of the importance of obesity as a diabetogenic factor, overweight in the newly-found diabetic subjects was considered.

$15 \%$ or more over the ideal weight (according to Broca) was taken as defining obesity and on this basis a high frequency of obesity was found, reaching $77 \%$ for certain ages (Fig. 7).

$171(51 \%)$ out of 332 newly found diabetics were obviously overweight. In the rural population, obesity was found in $69 \%$ on the tested subjects.

This fact supports the hypothesis of a diabetogenic role of obesity and raises the question of urgent controls as a prophylatic measure. 


\section{Glycosuria with normal blood sugar}

In addition to the people with newly-found clinical, chemical and latent Diabetes mellitus, glycosuria was noted $2 \mathrm{~h}$ after the glucose load in a high proportion of the normoglycaemic people. The group included sub-
The incidence of obesity in these subjects, assessed on the basis of criteria previously described was $27.5 \%$ (Fig. 9).

Glycosuria with normoglycaemia following a glucose load seems to indicate the existence of a separate category of disorders of carbohydrate metabolism.
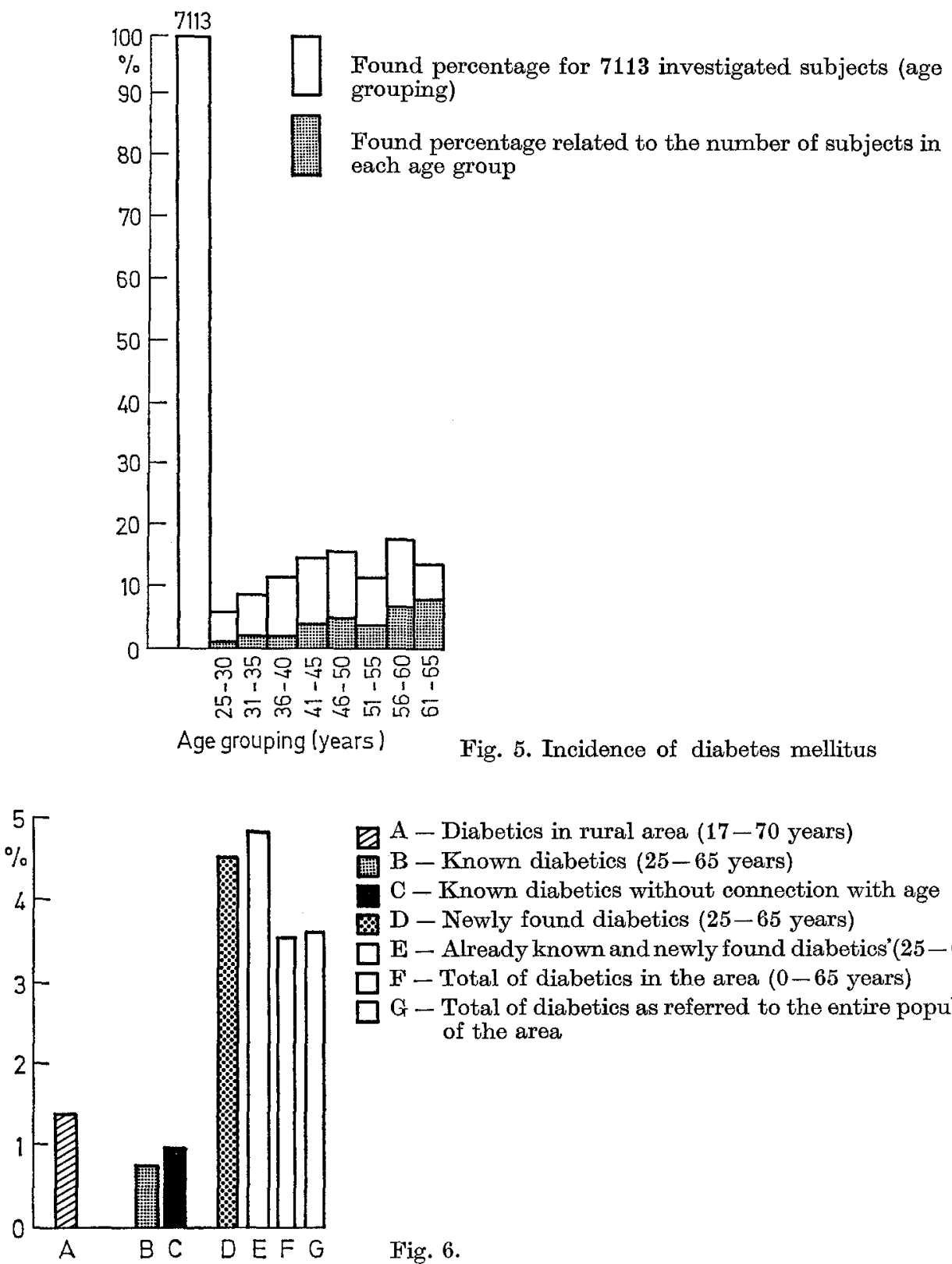
A - Diabetics in rural area (17 - 70 years)
B - Known diabetics (25-65 years)
$\mathrm{C}-\mathrm{Known}$ diabetics without connection with age
$\mathrm{D}-$ Newly found diabetics (25-65 years)
$\square$ E - Already known and newly found diabetics'(25 - 65 years)
$\square \mathbf{F}-$ Total of diabetics in the area $(0-65$ years)
$G$ - Total of diabetics as referred to the entire population of the area

jects initially with normoglycaemia (below the upper limit established for the appropriate age group) (Fig. 1) and with normal values at the second laboratory investigation.

Glycosuria with normoglycaemia, was found in $2.15 \%$ of the whole investigated population (the percentages by sex and age are recorded in Fig. 8).
When considering Diabetes mellitus, this situation leads to a significant but spurious overestimate of the prevalence of the disease in the whole population. Despite its apparently benign nature, subjects with renal glycosuria should be recorded and periodically re-examined.

The detection of Diabetes mellitus by sole reliance 
upon glycosuria, is both inadequate and erroneous. Any mass screening must include the measurement of blood sugar at the same time as testing for glycosuria, with

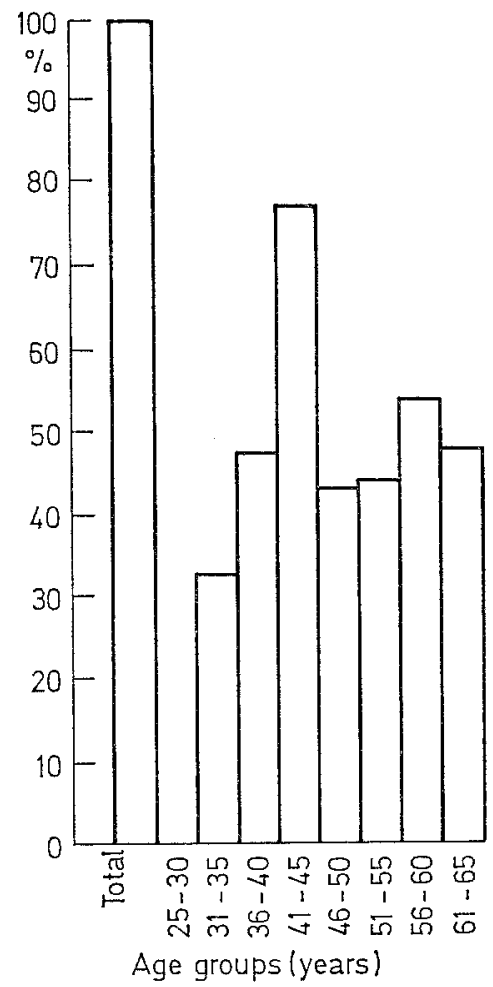

Fig. 7. Percentage of Incidence for obesity by newly found diabetics (age grouping)

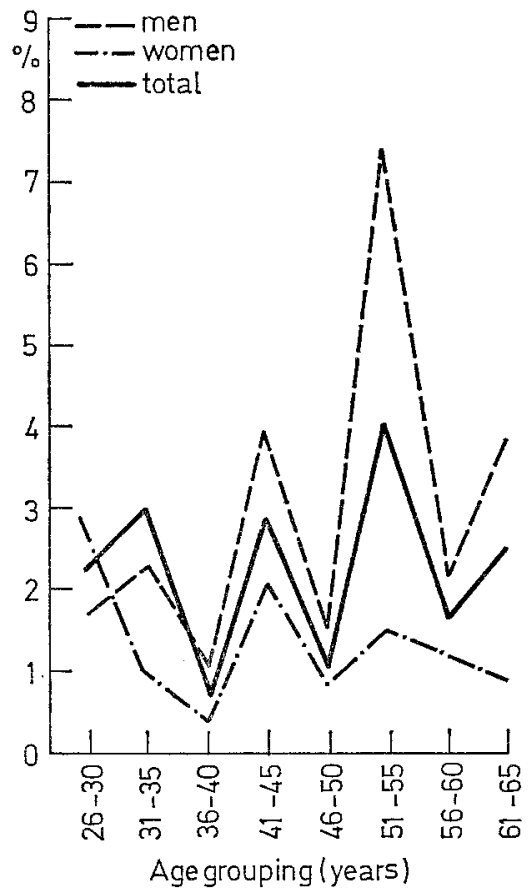

Fig. 8. Incidence of glucosuria by normal blood glucose, $2 \mathrm{~h}$ after the carbohydrate meal the individual checking of glucose tolerance in the doubtful cases.

\section{Conclusions}

- The most suitable method for mass detection of Diabetes mellitus is the measurement of blood sugar and the urine test for glucose two hours after an oral

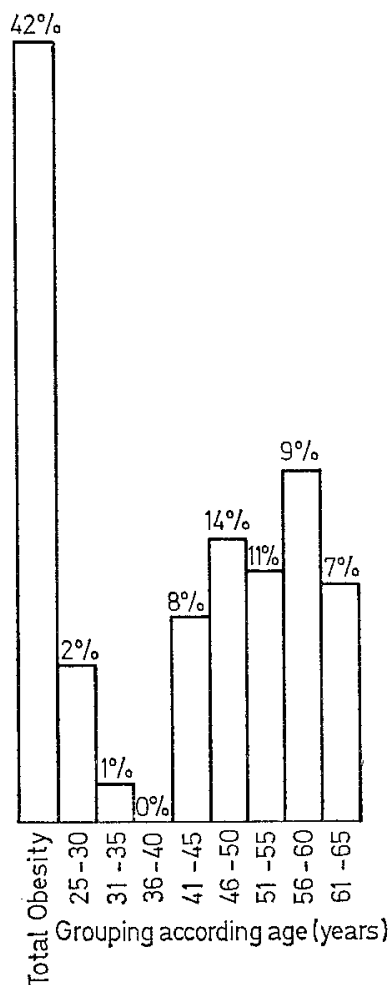

Fig. 9. Incidence of obesity (\%) depending on age by the subjects which showed glucosuria without hyperglycemia

glucose load, followed by individual investigation through the oral glucose tolerance test in doubtful cases.

- The application of this method in 1314 subjects in a Roumanian rural population and on 7113 persons in an urban population indicated a prevalence of Diabetes mellitus of $1.44 \%$, in the rural population and of $3.7 \%$, in the urban population.

A recent research made in München [6], found a clear prevalence of Diabetes mellitus in male subjects, aged under 50 . This fact was already suggested by the statistical data on Diabetes mellitus from A.C.B., regarding this disease in Bucharest from 1942-1970.

Obesity among the newly discovered diabetics was present in $51 \%$ in the urban population and $69 \%$ in the rural one.

The study has also pointed out, that, in addition to newly found cases of Diabetes mellitus, $2.15 \%$ of the subjects had glycosuria with normoglycaemia and normal GTT, suggesting that this group deserves special attention as a separate category. 


\section{References}

1. Mincu, I., Campeanu, S., Dumitrescu, C., Covanov, D., Georgescu, St., Mihaiache, N.: Cercetari privind unele aspecte ale epidemiologieie diabetului zaharat. Med. Interna 21, 813-822 (1969).

2. Duncan, G.G.: Diabetul zaharat in Bolile Metabolismului, vol. II, p. 1162-1163. București: Editura Medicala 1966.

3. Falta, W., Högler, F.: Die Zuckerkrankheit. Ed. IV. Halle (Saale): Veb. Karl Marhold 1953.

4. Gsell, O.: Epidemiologie des Diabetes. Dtsch. med. Wschr. 93, 2446 (1968).

5. Schliack, V.: Über die Diabetes Morbidität. Dtsch. med. Wschr. 90, 2321-2327 (1965).

6. Fritz, G.: Ergebnisse der Münchner Aktion zur Früherkennung von Diabetikern (1967) - Inaugural Dissertation - München 1969.

7. Butterfield, W.J.H.: Summary of results of the Beford Diabetes Survey. Proc. roy. Soc. Med. 57, 169 (1964).

8. - Priorities in medicine p. 30. The Nuffield Provincial Hospital Trust (1968).

9. Butturini, U., Negri, A.U.: Rivelazioni clinico-statistiche sul diabete giovanile. Atti del $1^{\circ}$ Congr. Naz. della Soc. Ital. di Diabetologia e del Simp. Naz. sul Diabete. Catania 16-18 Febr. 1966.

10. Cohen, A.M.: Prevalence of diabetes among different ethnic jewish group in Israel. Amer. Heart J. 65, 291 293 (1963).
11. O'Sullivan, J.B., Williams, R.F.: Early diabetes mellitus in perspective. J. Amer. med. Ass. 198, 579$582(1966)$.

12. Sharp, C.L., Butterfield, W.J.H., Keen, H.: Diabetes survey in Bedford, 1962, Proc. roy. Med. 57, 193 (1964).

13. Suchet, A.W., Suchet, A.: Glycosurie provoqué et depistage du diabète dans les collectivitiés. Presse Medicale 78, 1309-1312 (1970).

14. West, K.M., Kalbfleisch, J.M.: Glucose tolerance. Nutrition and diabetes in Uruguay, Venezuela, Malaya and East Pakistan. Diabetes 18, 9-12 (1966).

15. Pavel, I., Cazacu-Dobrescu, M., Covanov, D.: Depistarea sistematica a unor boli de nutritie în doua circumscriptii dun București. Med.-Interna 21, 147 (1964).

16. Pavel, I., Pieptea, R.: Diabetul. București, Ed. Med. 1955 .

17. Angeli, I. : Adatok a diabetes mellitus, epidemiologiajahoz, Orvosi. Hetilap. 111, 1159-1164 (1970).

18. Rodriguez, I. L., Goana, T., Poveda, O. : Epidemiologie du diabète. Cahiers de Medicine (Europa Medica) 11, $787-794(1970)$.

T. Mincu, M. D., Centre of Metabolic Diseases and Nutrition Hospital

„Dr. I. Cantacuzino", Bucharest, Roumania 